\title{
EFEKTIVITAS TERAPI KELOMPOK ASSERTIVENESS TRAINING TERHADAP KEMAMPUAN KOMUNIKASI ASERTIF PADA REMAJA DENGAN PERILAKU AGRESIF
}

\author{
Endang Mei Yunalia ${ }^{*}$, Arif Nurma Etika \\ Program Studi Ilmu Keperawatan Fakultas Ilmu Kesehatan Universitas Kadiri \\ *endang.mei@unik-kediri.ac.id
}

\begin{abstract}
ABSTRAK
Komunikasi merupakan dasar dari seluruh kegiatan interaksi sosial dalam kehidupan sehari - hari. Salah satu tujuan komunikasi adalah untuk meyampaikan keinginan dan perasaan pada orang lain, dimana dalam menyampaikan keinginan dan perasaan hendaknya penting untuk tetap memperhatikan hak orang lain atau yang disebut juga dengan komunikasi asertif. Kurangnya kemampuan remaja dalam melakukan komunikasi asertif menyebabkan tingginya kejadian perilaku agresif pada remaja. Kemampuan komunikasi asertif dapat ditingkatkan dengan memberikan terapi kelompok Asssertiveness Training. Tujuan penelitian ini untuk mengetahui efektivitas terapi kelompok Assertiveness Training terhadap kemampuan komunikasi asertif pada remaja dengan perilaku agresif. Penelitian ini merupakan penelitian Quasy Eksperimental menggunakan rancangan one group pre - post test with kontrol design. Populasi dalam penelitian ini adalah remaja dengan perilaku agresif. Sampel berjumlah 36 responden yang dipilih menggunakan purposive sampling yang terbagi dalam 2 kelompok yaitu kelompok intervensi dan kelompok kontrol. Uji statistik yang digunakan adalah Wilcoxon Signed Ranks Test. Hasil uji statistik menunjukkan p=0,004 (pvalue $<0,05)$, yang berarti terdapat pengaruh terapi kelompok Asssertiveness Training terhadap kemampuan komunikasi asertif pada remaja dengan perilaku agresif.
\end{abstract}

Kata kunci: assertiveness training, komunikasi asertif, perilaku agresif, remaja

\section{EFFECTIVENESS OF ASSERTIVENESS TRAINING GROUP THERAPY ON ASSERTIVENESS COMMUNICATION SKILLS IN ADOLESCENTS WITH AGGRESSIVE BEHAVIOUR}

\begin{abstract}
Communication is the basis of social interaction activities. One of the communication goals is to convey the wishes and feelings of others, where in conveying the desires and feelings it should be important to pay attention to the rights of others, this is also called assertive communication. The high incidence of aggressive behavior in adolescents one of which is caused by the lack of ability of adolescents in assertive communication. Assertive communication skills can be improved by providing Assertiveness Training group therapy. Research objectives to determine the effectiveness of Assertiveness Training group therapy on assertive communication skills in adolescents with aggressive behavior. This study use Quasy Experimental, one group pre - post test with kontrol design. The population in this study is adolescents with aggressive behavior. A sample of 36 respondents were selected using purposive sampling which is divided into 2 groups namely the intervention group and a control group. Data analysis using Wilcoxon Signed Ranks Test. The eresults showed that $p=0,004$ ( $p$-value $<0,05)$, it means there is an influence of Assertiveness Training group therapy on assertive communication skills in adolescents with aggressive behavior.
\end{abstract}

Keywords: assertiveness training, assertiveness communication, aggressive bahavior, adolescents 


\section{PENDAHULUAN}

Perilaku agresif merupakan salah satu bentuk ekspresi emosi individu akibat adanya suatu ketidakberhasilan yang dialami. Perilaku ini dapat diwujudkan dalam bentuk tindakan berupa merusak benda atau melakukan penyerangan kepada orang lain baik secara verbal ataupun non verbal yang dilakukan dengan unsur kesengajaan. Perilaku agresif ini adalah salah satu masalah yang sering terjadi pada remaja. Dampak dari perilaku agresif ini bisa menyebabkan kerugian baik pada individu yang melakukan perilaku agresif ataupun pada individu yang menerima perlakuan perilaku agresif (Shao, Liang, Yuan, \& Bian, 2014).

Kejadian perilaku agresif pada remaja jumlahnya terus mengalami peningkatan dari tahun ke tahun. Hal ini dibuktikan dengan data dari World Health Organization (WHO). World Health Organization telah melakukan survey tentang perilaku agresif pada remaja, dimana survey ini bertujuan untuk membandingkan prevalensi kasus kenakalan remaja di beberapa negara. Data yang didapatkan dari survey tersebut yaitu bahwa dari sejumlah 161.082 siswa, 36 - 69\% siswa laki - laki dan $13-32 \%$ siswa perempuan pernah terlibat dalam kejadian tawuran antar sekolah (Hall, 2012). Data dari Komisi Perlindungan Anak Indonesia (KPAI) menunjukkan kasus remaja yang berhubungan dengan hukum mengalami peningkatan antara tahun 2011 - 2016. Data tersebut antara lain kasus kekerasan fisik dan kekerasan psikis yang merupakan bentuk dari perilaku agresif (KPAI, 2016).

Data lain menunjukkan pada tahun 2016 terdapat 298 kasus kenakalan remaja dan diantaranya adalah kasus kekerasan fisik. Data ini menunjukkan peningkatan dibandingkan kejadian pada tahun 2015 (Arofa, Hudaniah, \& Zulfiana, 2018). Jumlah remaja di Provinsi Jawa Timur sendiri adalah sebesar 16, 19\% dari total jumlah penduduk (6.133.053 jiwa) (Yunalia, 2017). Kasus penganiayaan di Jawa Timur ditemukan sebanyak 554 kasus pada tahun 2014, kasus ini lebih tinggi dari tahun sebelumnya yaitu 484 kasus (BPS, 2014). Pemerintah Provinsi Jawa Timur juga menyampaikan dalam laporan capaian kinerja penyelenggaraan pemerintahan bahwa kasus kenakalan remaja di Jawa timur masih tinggi (Jatimprov, 2019).

Hasil survey awal yang dilakukan oleh peneliti di SMP 8 Kediri didapatkan data bahwa dari 14 siswa, 7 diantaranya sering melakukan perilaku agresif dalam bentuk ucapan/ verbal seperti mengancam teman jika keinginannya tidak dipenuhi, mengolok - olok dan menyindir. Selain itu, beberapa siswa juga memiliki riwayat melakukan kekerasan fisik, seperti menendang atau memukul teman ketika marah.

Kejadian perilaku agresif pada remaja dapat terjadi salah satunya adalah karena masa remaja merupakan masa dimana individu mulai mengalami adanya perubahan - perubahan, baik secara fisik maupun psikologis. Memasuki masa remaja, sebagian remaja mengartikan bahwa masa ini masa yang sulit dan memerlukan adaptasi, yang mana pada proses adaptasi ini akan mempengaruhi kondisi fisik maupun psikologis (Yunalia, 2017). Perkembangan emosi pada remaja merupakan masa kritis yang terjadi pada perkembangan individu. Perkembangan emosi masa remaja menyebabkan seseorang memiliki keinginan yang tinggi untuk menggali sesuatu yang berada di lingkungan ataupun orang di sekitarnya yang menjadi minat mereka. Hal ini menyebabkan remaja terkadang sulit untuk membedakan hal yang bersifat positif ataupun negatif. Akibat yang terjadi jika remaja sulit unutk membedakan hal bersifat positif ataupun negatif salah satunya adalah remaja bisa menjadi orang yang memberontak ataupun melakukan perilaku agresif (Lutfiani, Sri, \& Setyawati, 2018).

Ketika remaja melakukan tindakan atau perilaku agresif, maka hal tersebut bisa menyebabkan terjadinya masalah dalam menjalin hubungan interpersonal. Maka dari itu remaja harus memiliki kemampuan komunikasi asertif agar dalam menyampaikan keinginan atau pendapat kepada orang lain remaja dapat menyampaikan dengan baik sehingga tidak sampai menyebabkan terjadinya perilaku agresif pada remaja. Terapi kelompok assertiveness training adalah latihan yang dapat diberikan kepada remaja agar remaja mampu mengekpresikan atau mengungkapkan keinginannya secara tepat atau yang disebut dengan komunikasi asertif (Avşar \& Alkaya, 2017). Terapi assertiveness training dilakukan secara berkelompok karena terapi kelompok dapat memberikan banyak manfaat jika dilakukan pada remaja. Remaja yang menjadi peserta terapi akan mendapatkan penerimaan, dorongan, dan dapat berbagi pengalaman yang baik untuk menciptakan perilaku baru yang baik (A.Rezan Çeçen Erogul $\&$ Zengel, 2009). Tujuan penelitian ini adalah untuk mengetahui efektivitas Terapi Kelompok 
Assertiveness Training terhadap kemampuan komunikasi asertif pada remaja.

\section{METODE}

Rancangan penelitian ini adalah Quasy Experimental design dengan menggunakan rancangan one group pre and post test with kontrol design. Populasi dalam penelitian adalah remaja dengan perilaku agresif yaitu sebanyak 42 siswa dengan tingkat perilaku agresif sedang, tinggi, dan sangat tinggi (Penelitian ini dilakukan di SMP 8 Kediri, pemilihan subyek dilakukan pada bulan Mei 2019 di kelas VIII SMP 8 Kediri yang terdiri dari 11 kelas dengan jumlah 319 siswa. Dari 319 siswa, didapatkan 147 siswa dengan perilaku agresif rendah, sedang, tinggi dan sangat tinggi).

Sampel berjumlah 36 responden yang dipilih menggunakan tekhnik purposive sampling yang terbagi menjadi 2 kelompok yaitu kelompok intervensi dan kelompok control dengan jumlah responden yaitu sejumlah 18 responden untuk kelompok intervensi dan 18 responden untuk kelompok kontrol yang menenuhi kriteria inklusi, yaitu 1) Remaja dengan perilaku agresif sedang, tinggi, atau sangat tinggi, 2) Bersedia berpartisipasi dalam penelitian. Sedangkan untuk kriteria eksklusinya yaitu: 1) Tidak dapat melakukan aktivitas fisik/ sedang tirah baring, 2) Memutuskan untuk tidak melanjutkan pengisian ataupun tidak mengisi kuesioner dengan lengkap.

Instrumen yang digunakan untuk mengukur perilaku agresif adalah Buss - Perry Aggression Questionnaire (BPAQ). Hasil analisis instrument didapatkan nilai koefisien alpha cronbach 0,852 yang artinya reliabilitas skala agresivitas berada pada taraf yang baik dan dari hasil uji validitas didapatkan $\mathrm{r}$ tabel skala agresivitas adalah 0,1956. Kuesioner BPAQ memuat 4 kategori pertanyaan tentang perilaku agresif yaitu agresif fisik, agresif verbal, amarah dan permusuhan yang tertuang dalam 27 item pertanyaan. dan instrumen yang digunakan untuk mengukur kemampuan komunikasi asertif responden adalah Assertiveness Scale for Adolescents (ASA), dan hasil dari kuesioner ASA dibagi menjadi 3 kategori yaitu komunikasi asertif, komunikasi pasif dan komunikasi agresif. Uji statistik yang digunakan adalah Wilcoxon Signed Ranks Test. Setelah mendapatkan keterangan laik etik (No. 31/EC/KEPK-UNIK/05/2019), peneliti memulai pelaksanaan penelitian dengan memberikan penjelasan dan tujuan penelitian dan selanjutnya peneliti memberikan lembar inform consent yang harus ditandatangani jika calon responden bersedia menjadi responden.

Setelah lembar inform consent ditandatangani, maka peneliti membagi responden ke dalam 2 kelompok yaitu keompok intervensi dan kelompok kontrol. Selanjutnya kedua kelompok dilakukan penilaian kemampuan komunikasi asertif sebelum dan sesudah tindakan yaitu dengan menggunakan terapi kelompok Assertiveness Training untuk kelompok intervensi, sedangkan untuk kelompok kontrol dalam penelitian ini tidak dilakukan perlakuan. Kelompok intervensi dibagi menjadi 2 kelompok, sehingga masing - masing kelompok terdiri dari 9 peserta terapi. Terapi kelompok Assertiveness Training dilakukan selama 5 sesi, dan pada masing - masing sesi dilakukan selama $30-45$ menit.

\section{HASIL}

Responden pada penelitian ini adalah siswa kelas VIII yang semuanya berada pada rentang usia 12 - 15 tahun, sebagian besar responden memiliki jenis kelamin laki - laki baik pada kelompok intervensi $(55,6 \%)$ dan pada kelompok kontrol (72,2\%). Sebagian besar responden merupakan anak pertama $(66,7 \%)$ baik pada kelompok intervensi maupun kelompok kontrol, yang mana hampir seluruh dari responden memiliki jumlah saudara $2-3$, pada kelompok intervensi sebesar $77,8 \%$ dan pada kelompok kontrol 72,2\%. Responden pada kelompok intervensi setengahnya orang yg terdekat dalam keluarga adalah ayah dan ibu $(50 \%)$, sedangkan pada kelompok kontrol sebagian besar memiliki kedekatan dengan ayah dan ibu $(72,2 \%)$.

Tabel 1 menunjukkan bahwa hampir seluruh responden tinggal bersama dengan orang tua, pada kelompok intervensi sebesar 94,4\% dan pada kelompok kontrol $88,9 \%$, yang mana sebagian besar orang tua responden pada kelompok intervensi memiliki penghasilan $>$ Rp 3.000.000 (61,1\%) dan sebagian besar orang tua responden pada kelompok kontrol memiliki penghasilan $\mathrm{Rp}$ 1.500.000-Rp 3.000.000 atau setara dengan UMR Kota Kediri, sedangkan sebagian besar pendidikan orang tua pada kelompok intervensi memiliki pendidikan menengah $(66,7 \%)$ dan hampir seluruh orang tua responden pada kelompok kontrol memiliki pendidikan menengah $(83,3 \%)$. 
Tabel 1.

Karakteristik Responden $\left(\mathrm{n}_{1}=18, \mathrm{n}_{2}=18\right)$

\begin{tabular}{|c|c|c|c|c|}
\hline \multirow[t]{2}{*}{ Variabel } & \multicolumn{2}{|c|}{ Kelompok Intervensi } & \multicolumn{2}{|c|}{ Kelompol Kontrol } \\
\hline & $\mathrm{f}$ & $\%$ & $\mathrm{f}$ & $\%$ \\
\hline \multicolumn{5}{|l|}{ Usia } \\
\hline $12-15$ tahun & 18 & 100 & 18 & 100 \\
\hline $15-18$ tahun & 0 & 0 & 0 & 0 \\
\hline \multicolumn{5}{|l|}{ Jenis Kelamin } \\
\hline Laki - laki & 10 & 55,6 & 13 & 72,2 \\
\hline Perempuan & 8 & 44,4 & 5 & 27,8 \\
\hline \multicolumn{5}{|l|}{ Urutan Anak } \\
\hline Ke1 & 12 & 66,7 & 12 & 66,7 \\
\hline $\mathrm{Ke} 2$ & 4 & 22,2 & 4 & 22,2 \\
\hline Ke 3 & 2 & 11,1 & 2 & 11,1 \\
\hline $\mathrm{Ke}>3$ & 0 & 0 & 0 & 0 \\
\hline \multicolumn{5}{|l|}{ Jumlah Saudara } \\
\hline Anak tunggal & 0 & 0 & 2 & 11,1 \\
\hline $2-3$ saudara & 14 & 77,8 & 13 & 72,2 \\
\hline$>3$ saudara & 4 & 22,2 & 3 & 16,7 \\
\hline \multicolumn{5}{|c|}{ Orang Terdekat dalam Keluarga } \\
\hline Ayah & 1 & 5,6 & 1 & 5,6 \\
\hline Ibu & 6 & 33,3 & 2 & 11,1 \\
\hline Ayah dan Ibu & 9 & 50 & 13 & 72,2 \\
\hline Lainnya & 2 & 11,1 & 2 & 16,7 \\
\hline \multicolumn{5}{|l|}{ Tempat Tinggal } \\
\hline Bersama orangtua & 17 & 94,4 & 16 & 88,9 \\
\hline Tidak bersama orangtua & 1 & 5,6 & 2 & 11,1 \\
\hline \multicolumn{5}{|l|}{ Keberadaan Sahabat Dekat } \\
\hline Ada & 18 & 100 & 18 & 100 \\
\hline Tidak & 0 & 0 & 0 & 0 \\
\hline \multicolumn{5}{|l|}{ Pendidikan Orangtua } \\
\hline Dasar & 4 & 22,2 & 3 & 16,7 \\
\hline Menengah & 12 & 66.7 & 15 & 83,3 \\
\hline Tinggi & 2 & 11,1 & 0 & 0 \\
\hline \multicolumn{5}{|l|}{ Penghasilan Orangtua } \\
\hline$<1.5000 .000$ & 1 & 5,6 & 0 & 0 \\
\hline $1.500 .000-3.000 .000$ & 6 & 33,3 & 14 & 77,8 \\
\hline$>3.000 .000$ & 11 & 61,1 & 4 & 22,2 \\
\hline
\end{tabular}

Tabel 2.

Efektivitas Terapi Kelompok Assertiveness Training terhadap Kemampuan Komunikasi Asertif pada Remaja dengan Perilaku Agresif $\left(\mathrm{n}_{1}=18, \mathrm{n}_{2}=18\right)$

\begin{tabular}{|c|c|c|c|c|c|c|c|c|}
\hline \multirow{3}{*}{$\begin{array}{l}\text { Kategori } \\
\text { komunikas }\end{array}$} & \multicolumn{4}{|c|}{ Kelompok Intervensi } & \multicolumn{4}{|c|}{ Kelompok Kontrol } \\
\hline & \multicolumn{2}{|c|}{ Sebelum } & & \multirow{2}{*}{$\begin{array}{c}\text { Sesudah } \\
\%\end{array}$} & \multicolumn{2}{|c|}{ Sebelum } & \multicolumn{2}{|c|}{ Sesudah } \\
\hline & $\mathrm{f}$ & $\%$ & $\mathrm{f}$ & & $\mathrm{f}$ & $\%$ & $\mathrm{f}$ & \\
\hline Pasif & 0 & 0 & 0 & 0 & 0 & 0 & 0 & 0 \\
\hline Agresif & 14 & 77,8 & 2 & 11,1 & 12 & 66,7 & 10 & 55,6 \\
\hline Asertif & 4 & 22,2 & 16 & 88,9 & 6 & 33,3 & 8 & 44,4 \\
\hline \multicolumn{5}{|c|}{$P$ value: 0,004} & \multicolumn{4}{|c|}{ P value: 0,077} \\
\hline
\end{tabular}


Tabel 2, dapat diketahui bahwa kelompok intervensi sebagian besar responden $(77,8 \%)$ memiliki kemampuan komunikasi pada tingkat agresif, sedangkan setelah mengikuti terapi kelompok Assertiveness Training, responden yang berada pada tingkat komunikasi agresif menjadi 2 responden $(11,1 \%)$ dan responden yang memiliki kemampuan komunikasi asertif meningkat menjadi 16 responden $(88,9 \%)$. Data menunjukkan terdapat perubahan tingkat kemampuan komunikasi asertif pada remaja dengan perilaku agresif, dengan nilai $\mathrm{p}$ dari uji statistik diperoleh angka 0,004 ( $p$ value $<0,005)$, artinya terdapat pengaruh terapi kelompok Assertiveness Training terhadap Kemampuan Komunikasi Asertif pada Remaja dengan Perilaku Agresif.

Selanjutnya, pada kelompok kontrol dapat diketahui bahwa 12 responden $(66,7 \%)$ memiliki kemampuan komunikasi pada tingkat agresif dan 6 responden $(33,3 \%)$ memiliki kemampuan komunikasi asertif, sedangkan hasil post test, responden yang berada pada tingkat komunikasi agresif menjadi 10 responden $(55,6 \%)$ dan responden dengan kemampuan komunikasi asertif meningkat menjadi 8 responden $(44,4 \%)$. Data tersebut menunjukkan terdapat perubahan tingkat kemampuan komunikasi asertif pada kelompok kontrol yang tidak mendapatkan perlakuan. Hasil uji statistik menunjukkan $p$ value yaitu 0,077 ( $p$ value $<0,005)$, yang artinya tidak terdapat perubahan kemampuan komunikasi asertif yang bermakna pada kelompok kontrol antara sebelum dan sesudah pelaksanaan terapi kelompok Assertiveness Training.

Tabel 3.

Tabel Wilcoxon tingkat Kemampuan Komuniaksi Asertif Sebelum dan Sesudah Dilakukan Terapi Kelompok Assertiveness Training pada Remaja dengan Perilaku Agresif $\left(\mathrm{n}_{1}=18, \mathrm{n}_{2}=18\right)$

\begin{tabular}{llcl}
\hline & & $\mathrm{N}_{1}$ (Intervensi) & $\mathrm{N}_{2}$ (Kontrol) \\
\hline Komunikasi asertif sesudah-sebelum & Negative Ranks & $3^{\mathrm{a}}$ & $3^{\mathrm{a}}$ \\
& Positive Ranks & $14^{\mathrm{b}}$ & $11^{\mathrm{b}}$ \\
& Ties & $1^{\mathrm{c}}$ & $4^{\mathrm{c}}$ \\
\hline
\end{tabular}

$p$-value $\left(\mathrm{n}_{1}\right)=0,004^{*}, p$-value $(\mathrm{n} 2)=0,077^{*}$

*Signifikan pada $\alpha: 0,05$

Keterangan Kelompok Intervensi $\left(\mathrm{n}_{1}=18\right)$ :

a. Kemampuan komunikasi asertif sesudah < kemampuan komunikasi asertif sebelum

b. Kemampuan komunikasi asertif sesudah > kemampuan komunikasi asertif sebelum

c. Kemampuan komunikasi asertif sesudah $=$ kemampuan komunikasi asertif sebelum

Berdasarkan tabel 3 diketahui bahwa dari keseluruhan responden pada kelompok intervensi didapatkan 14 responden yang mengalami peningkatan kemampuan komunikasi asertif, 3 responden yang mengalami penurunan kemampuan komunikasi asertif dan 1 responden yang memiliki kemampuan komunikasi aertif yang sama Keterangan Kelompok Kontrol $\left(\mathrm{n}_{2}=18\right)$ :

a. Kemampuan komunikasi asertif sesudah $<$ kemampuan komunikasi asertif sebelum

b. Kemampuan komunikasi asertif sesudah $>$ kemampuan komunikasi asertif sebelum

c. Kemampuan komunikasi asertif sesudah $=$ kemampuan komunikasi asertif sebelum

Berdasarkan tabel 3 diketahui bahwa dari keseluruhan responden pada kelompok kontrol didapatkan 11 responden yang mengalami peningkatan kemampuan komunikasi asertif, 3 responden yang mengalami penurunan kemampuan komunikasi asertif dan 4 responden yang memiliki kemampuan komunikasi asertif yang sama.

\section{PEMBAHASAN}

Kemampuan komunikasi asertif pada remaja dengan perilaku agresif sebelum dilakukan terapi kelompok assertiveness training

Hasil analisis dapat diambil kesimpulan bahwa terapi kelompok Assertiveness Training memberikan hasil peningkatan kemampuan komunikasi asertif. Data pada tabel III didapatkan data pada remaja dengan perilaku agresif di SMP 8 Kediri sebelum dilakukan terapi kelompok Assertiveness Training, terdapat 14 responden $(77,8 \%)$ memiliki kemampuan komunikasi pada tingkat agresif dan 4 responden $(22,2 \%)$ memiliki kemampuan komunikasi asertif pada kelompok intervensi, sedangkan pada kelompok kontrol sebagian besar responden yaitu sebanyak 12 responden $(66,7 \%)$ memiliki kemampuan komunikasi pada 
tingkat agresif dan 6 responden $(33,3 \%)$ memiliki kemampuan komunikasi asertif.

Berdasarkan data tersebut, dapat disimpulkan bahawa remaja dengan perilaku agresif kurang memiliki kemampuan komunikasi asertif. Hasil penelitian ini sejalan dengan penelitian yang dilakukan oleh Abdulkarim, Zainul dan Maryani yang menyebutkan bahwa kenakalan remaja yang berhubungan dengan perilaku agresif ada kaitannya dengan kemampuan komunikasi asertif. Remaja dengan tingkat asertivitas yang rendah akan mudah terpengaruh oleh perilaku negative sehingga mereka cenderung melakukan perilaku agresif (Abdulkarim, Zainul, \& Maryani, 2014).

Kurangnya kemampuan komunikasi asertif atau kemampuan untuk mengkomuniksikan apa yang diinginkan, diharapkan, dirasakan, dan dipikirkan kepada orang lain dengan terbuka, menghargai diri sendiri, mengekspresikan perasaan secara proporsional dengan tetap menjaga hak orang lain pada remaja dapat terjadi karena berbagai faktor (Omura et al., 2017). Salah satu faktor yang berpengaruh adalah keluarga atau tempat dimana remaja tersebut tinggal. Data di tabel I menunjukkan bahwa hampir seluruh responden tinggal bersama orang tua $(94,4 \%)$, dengan sebagain besar orang tua memiliki pendidikan menengah $(66,7 \%)$. Hal ini berarti, remaja setiap hari melakukan interaksi dengan orang tua. Remaja yang tinggal bersama dengan orang tua bisa melakukan perilaku agresif dan kurang memiliki kemampuan komunikasi asertif dapat dipengaruhi karena karakteristik pendidikan orang tua yang rendah (Gowi, Hamid, \& Nuraini, 2012). Dimana, orang tua dengan pendidikan menengah dapat saja kurang memiliki pengetahuan tentang stimulasi cara komunikasi asertif pada remaja.

Data pada tabel 2 menunjukkan bahwa 4 responden $(22,2 \%)$ memiliki kemampuan komunikasi asertif, dimana responden ini memiliki jenis kelamin laki - laki. Sedangkan dari telaah data, 8 responden perempuan memilki kemampuan komunikasi agresif. Hasil penelitian ini sesuai dengan teori yang menyebutkan bahwa kemampuan dan perilaku asertif dipengaruhi oleh jenis kelamin, dan remaja dengan jenis kelamin laki - laki lebih mampu berkomunikasi secara asertif dibandingkan remaja perempuan karena peran dan pendidikan laki - laki cenderung dididik untuk mampu bersikap tegas dan kompetitif, sehingga laki - laki mampu asertif dibandingkan perempuan (Novalia \& Dayakisni, 2013).

Hasil peneltian juga menunjukkan bahwa sebagian besar responden merupakan anak urutan pertama dalam keluarga. Hasil penelitian ini sejalan dengan pendapat Ardebli dan Golshani yang menyatakan bahwa urutan anak berpengaruh terhadap model pembentukan kebiasaan tentsng bagaimana berinteraksi dengan orang lain, temasuk dalam melakukan komunikasi (Ardebili \& Golshani, 2016). Anak urutan pertama kurang memiliki kemampuan komunikasi asertif, bisa jadi disebabkan karena kurangnya variasi perilaku yang digunakan atau yang diadaptasi oleh remaja.

Disimpulkan bahwa kemampuan komunikasi asertif pada responden sebelum dilakukan terapi kelompok Assertiveness Training sebagian besar masuk ke dalam komunikasi tingkat agresif. Hasil penelitian ini diperkuat dengan pendapat yang disampaikan oleh Rezan, Erogul dan Zengel yang menyatakan bahwa kemampuan komunikasi asertif yang dimiliki oleh remaja dengan perilaku agresif masih rendah walaupun remaja tinggal bersama dengan orang tua. Banyak hal menyebabkan remaja terhambat untuk melakukan komunikasi asertif, diantaranya adalah jenis kelamin, pengaruh dari sahabat dekat, dan pendidikan orang tua yang berpengaruh terhadap kemampuan komunikasi asertif, sehingga remaja perlu mendapatkan terapi latihan asertif agar remaja dengan perilaku agresif dapat melakukan komunikasi asertif dalam menjalin hubungan interpersonal (A.Rezan Çeçen Erogul \& Zengel, 2009).

\section{Kemampuan komunikasi asertif pada remaja dengan perilaku agresif sesudah dilakukan terapi kelompok assertiveness training}

Tabel 2 menunjukkan bahwa setelah mengikuti terapi kelompok Assertiveness Training, responden yang berada pada tingkat komunikasi tingkat agresif menjadi 2 responden $(11,1 \%)$ dan responden yang memiliki kemampuan komunikasi asertif meningkat menjadi 16 responden $(88,9 \%)$. Hal ini membuktikan adanya peningkatan 
jumlah responden yang memiliki kemampuan dalam melakukan komunikasi asertif.

Tabel 2 juga menunjukkan bahwa dari keseluruhan responden didapatkan 11 responden yang mengalami peningkatan kemampuan komunikasi asertif, 3 responden yang mengalami penurunan kemampuan komunikasi asertif dan 4 responden yang memiliki kemampuan komunikasi asertif yang sama. Hasil tersebut menunjukkan bahwa terapi kelompok Assertiveness Training efektif untuk meningkatkan kemampuan komunikasi asertif pada remaja. Kemampuan komunikasi asertif pada kelompok kontrol juga mengalami peningkatan, walaupun tidak signifikan. Hasil penelitian ini diperkuat dengan hasil penelitian yang menyatakan bahwa remaja yang mendapatkan latihan asertif mengalami peningkatan kemampuan komunikasi asertif yang signifikan (A.Rezan Çeçen Erogul \& Zengel, 2009).

Terapi Assertiveness Training dapat menimbulkan perilaku baru tentang komunikasi asertif karena dalam melakukan latihan atau terapi, anggota kelompok dapat melakukan adaptasi tentang komunikasi asertif yang ditunjukkan oleh anggota yang lain yang dapat diperoleh melalui kegiatan bermain peran, berlatih untuk mengajukan pendapat dengan tepat, memberikan dorongan daripada kritik dan memberikan pujian (A.Rezan Çeçen Erogul \& Zengel, 2009). Terapi Assertiveness Training yang dilakukan secara berkelompok juga dapat meningkatkan kemampuan komunikasi asertif karena dalam terapi ini peserta dilatih untuk dapat melakukan komunikasi interpersonal dengan tepat, mampu menyampaikan maksud dengan baik dan melatih peserta untuk memahami orang lain sehingga dari komunikasi asertif ini dapat meningkatkan kemampuan atau interaksi interpersonal (Gultekin, Odzemir, \& Budak, 2018).

Tingkat kemampuan komunikasi asertif responden memiliki kategori yang berbeda setelah dilakukan terapi kelompok Assertriveness Training. Sebagain besar responden mengalami peningkatan kemampuan komunikasi asertif, namun sebagian kecil responden berada pada tingkat komunikasi asertif yang sama seperti sebelum mendapatkan terapi kelompok Assertiveness Training. Sebagian kecil responden yang tidak mengalami peningkatan kemampuan komunikasi asretif ini terjadi karena selama terapi peserta kurang aktif. Hal ini ternyata sejalan dengan penelitian terdahulu yang menyatakan bahwa dalam pealsaan latihan asertif, peserta yag tidak menunjukkan adanya perubahan kemampuan asertivitas disebabkan karena peserta kurang interaktif saat dilakukan terapi (Ninawati, 2012).

\section{SIMPULAN}

Remaja dengan perilaku agresif setelah diberikan intervensi dengan terapi kelompok Assertiveness Training dan tanpa diberikan terapi, terapi kelompok Assertiveness Training menunjukkan peningkatan kemampuan komunikasi asertif yang signifikan, artinya terapi kelompok Assertiveness Training efektif untuk meningkatkan kemampuan komunikasi asertif pada remaja dengan perilaku agresif.

\section{DAFTAR PUSTAKA}

A.Rezan Çeçen Erogul, \& Zengel, M. (2009). The Effectiveness of an Assertiveness Training Programme on Adolescents , Assertiveness Level. Elementary Education Online, 8(2), 485-492.

Abdulkarim, A., Zainul, A., \& Maryani, E. (2014). Perilaku Asertif dan Kecenderungan Kenakalan Remaja Berdasarkan Pola Asuh dan Peran Media Massa. Jurnal Psikologi, 41(1), 74-88.

Ardebili, E. F., \& Golshani, F. (2016). Early Maladaptive Schemas and Aggression Based on the Birth Order of Children. Modern Applied Science, 10(9), 14-21. https://doi.org/10.5539/mas.v10n9p14

Arofa, I. Z., Hudaniah, \& Zulfiana, U. (2018). Pengaruh Perilaku Bullying terhadap Empati Ditinjau dari Tipe Sekolah. Jurnal Ilmiah Psikologi Terapan, 06(01), 74-92.

Avşar, F., \& Alkaya, S. A. (2017). Journal of Pediatric Nursing The effectiveness of assertiveness training for school-aged children on bullying and assertiveness level. Journal of Pediatric Nursing, 36, 186-190. https://doi.org/10.1016/j.pedn.2017.06.02 0

Gowi, A., Hamid, A. Y., \& Nuraini, T. (2012). Penurunan Perilaku Kekerasan Orangtua pada Anak Usia Sekolah melalui Latihan 
Asertif. Jurnal Keperawatan Indonesia, 15(3), 201-206.

Gultekin, A., Odzemir, A., \& Budak, F. (2018). The Effect of Assertiveness Education on Communication Skills Given to Nursing Students. International Journal of Caring Sciences, 11(1), 395402.

Hall, C. M. F. (2012). Understanding aggressive behaviour across the lifespan. https://doi.org/10.1111/j.1365-

2850.2012.01902.x

Jatimprov. (2019). Evaluasi Hasil Pelaksanaan RKPD dan Capaian Kinerja Penyelenggaraan Pemerintahan, 1-467.

KPAI. (2016). Rincian Tabel Data.

Lutfiani, D., Sri, \& Setyawati, P. (2018). Hubungan Antara Kecerdasan Emosional dengan Perilaku Agresif Siswa kelas VIII SMP Negeri 8 Kediri Tahun Ajaran 2017/ 2018. Simki-Pedagogia, 02(03).

Ninawati, T. M. (2012). Training Komunikasi Asertif Untuk Mengingkatkan Perilaku Asertif Terhadap Keterampilan kerjasama Pada Pre Operational First Officer PT.X.

Novalia, \& Dayakisni, T. (2013). Perilaku Asertif dan Kecenderungan menjadi Korban Bullying. Jurnal Ilmiah Psikologi Terapan, 01(01), 172-178.

Omura, M., Maguire, J., Levett-jones, T., \& Elizabeth, T. (2017). The Effectiveness of Assertiveness Communication Training Programs for Healthcare Professionals and Students: A systematic review. International Journal of Nursing Study, 76(September), 120-128. https://doi.org/10.1016/j.ijnurstu.2017.09. 001

Shao, A., Liang, L., Yuan, C., \& Bian, Y. (2014). A Latent Class Analysis of Bullies, Victims and Aggressive Victims in Chinese Adolescence: Relations with Social and School Adjustments. Plos One, 9(4). https://doi.org/10.1371/journal.pone.0095 290
Yunalia, E. M. (2017). Hubungan antara Konsep Diri dengan Penerimaan Perubahan Fisik Remaja Putri pada Masa Pubertas. Nursing Science Jurnal, 1, 3036. 